DOI: https://doi.org/10.47405/mjssh.v6i9.1025

\begin{tabular}{|c|c|}
\hline 4 & Malaysian Journal of Social Sciences and Humanities (MJSSH) \\
\hline $\begin{array}{l}\text { Malaysian Juoural of } \\
\text { Social ccciecces and }\end{array}$ & Volume 6, Issue 9, September 2021 \\
\hline (MJ-sSH) & e-ISSN : 2504-8562 \\
\hline & $\begin{array}{l}\text { Journal home page: } \\
\text { www.msocialsciences.com }\end{array}$ \\
\hline
\end{tabular}

\title{
What Drives Performance Measurement in NGOs?: A Case Study from Pakistan
}

\author{
Sulaiman Tahajuddin ${ }^{1}$, Syed Sarmad Hasan ${ }^{1}$, Abdul Wahid Mohd Kassim ${ }^{1}$ \\ ${ }^{1}$ Fakulti Perniagaan, Ekonomi dan Perakaunan, Universiti Malaysia Sabah (UMS) \\ Correspondence: Sulaiman Tahajuddin (sulaiman@ums.edu.my)
}

\begin{abstract}
The purpose of this research paper is to understand how an NGO in Pakistan perceives the utility of its performance measurement system and thus what drives design of its PMS. The study explores the phenomenon from the perspective of NGO managers by applying qualitative approach and using critical realism to explore the issue. The paper presents the findings on the basis of an instrumental case study conducted in Pakistan. The research identifies the main objective of PMS in this NGO is to help the organization remain sustainable and its managers' desire for legitimacy has deeply influenced the design of the PMS of the NGO. Results suggest managers perceive organizational credibility and not the accountability as the most important factor in determining its sustainability. The evidence is based on findings of a single NGO case study from Pakistan. Furthermore, the findings are based only on the perceptions of the managers of the selected organisation. Future research including perception of other stakeholders in other NGOs may help in deepening the understanding of the issue and validating the presented results. However, given that little research has been conducted within the NGO sector on drivers of performance measurement this research provides useful evidence that can be further developed. The paper specifically contributes by extending prior PM literature in an NGO environment. It has implications for the further development of legitimacy theories in the NGO sector. It raises issues about how primary focus of reporting in NGOs is shifting from accountability to showcasing.
\end{abstract}

Keywords: Performance measurement, NGO, Legitimacy, Credibility, Pakistan

\section{Introduction}

Knowing how an organization is performing is important for reasons unique to each stakeholder (Waldron, 2017). For instance, financial investors are concerned about the safety of their investments in the organization and the expected returns on their investments (Berk \& DeMarzo, 2017); whereas regulators are interested in knowing about compliance matters, customers, on the other hand, need to ensure about the quality of products or services they receive and managers fret about market share and the growth rate. With such a widely spread interest in the performance of organizations it is hardly surprising to note that the issue of performance measurement (PM) has attracted researchers' attention since long. It is estimated that approximately 100,000 items have been published on PM between 1994 and 2011 (Camp \& Braet, 2016). However, a vast majority of these articles have focused on the forprofit organizations in the private sector, a lesser number of these deal with governmental organizations and only a few have specifically addressed PM in the non-governmental organizations or NGOs. With the exponential rise in the number and size of NGOs around the world in the past couple 
of decades there is an acute need for primary research on issues of measuring performance of NGOs. This study attempts to contribute to the scant literature available on PM in NGOs.

There are currently more than 120,000 NGOs registered in Pakistan (Pakistan Centre for Philanthropy, 2017) but of these only 45,000 were found to be actively operating by Nisaa, Javed and Akhtar (2015). NGOs in Pakistan range from small grass-root level voluntary groups to large well structured organizations engaging thousands of paid employees and offices scattered around the country (Rasheed, Shahzad, Conroy, Nadeem, \& Siddique, 2017). Researchers have highlighted the role these NGOs play in the Pakistani society but little attention has been paid to studying how efficiently or effectively these organizations operate (Bhatti, 2016; Nisaa et al., 2015). Between 1990 and 2015, about 100,000 NGOs got registered in Pakistan (Pakistan Centre for Philanthropy, 2017) but 60,000 of these closed down within two years of inception (Saxena \& Muhammad, 2018). Reason for this dismally low survival rate as reported by Nazuk and Shabbir (2018) was lack of trust between Pakistani NGOs and its stakeholders. Although the study did not offer any explanation why there was lack of trust, it did mention absence of PM systems in the failed NGOs. Therefore, it can be reasonably argued that the abortive NGOs must not have been performing efficiently and/or effectively and thus they lost trust and consequently failed to raise adequate funds needed for survival. Such a large number of failed NGOs highlight the importance of performance measurement in NGOs.

In recent years several studies have been reported globally which focus on the issues NGOs face in conducting performance measurement but only a few of these studies have explored why NGOs measure its performance or how it designs its PM system (Moxham, 2014). Specifically, no research could be found from Pakistan investigating what factors influence an NGO's decision to measure its performance and design its performance measuring system.

Purpose of this study was to investigate why NGOs in Pakistan conduct performance measurement and what is the key factor which influences design of its PM system. The study explored the issue from the perspective of managers of a selected NGO in Pakistan by using qualitative approach and applying instrumental case study method.

Worth (2014) posited that most NGOs have some system of performance reporting so it could be deduced that these NGOs must have first measured the performance. While exploring the reasons why NGOs measure its performance Ebrahim (2010) identified accountability as the core motive, whereas, LeRoux and Wright (2010) in their study found capacity building as the main driver of PM in NGOs. Yet others have suggested mimetic isomorphism as explanation why NGOs implement PMS which is quite similar to the ones found in the private sector (Phelan, 2014). Mimetic isomorphism is a concept that organizations under social pressure tends to imitate other more successful organizations in the environment. However, some scholars and many professional working in NGOs have disputed the above claims and maintain that in general NGOs measure performance simply because donors ask for it (Wadongo \& Abdel-Kader, 2014). However, no empirical data regarding this issue is available on Pakistani NGOs which may be compared with the world view. Thus, the first research question this study investigated was:

RQ1: Why an NGO in Pakistan measures its performance?

Answer to this question could help in understanding the main motivation for an NGO in operating a performance measurement system (PMS). Once an NGO decides in principle that performance will be measured next step is to design the PMS. There are several frameworks and tools for measuring performance which are available to NGOs. Maas and Liket (2011) classified performance measuring frameworks into three categories in terms of its focus; process-focused models, outcome-focused models, and monetarised models. While Osborne (2013) categorized PM models as Rationale models, Political Models, and Organizational Excellence Models. The question of interest here is how an NGO decides which model is more suitable for them. In short, what influences the NGO's decision of selecting a framework or model for its PM. Therefore, the second research question this study explored was: 


\section{RQ2: What drives design of performance measuring system in an NGO?}

Extensive literature review was conducted and primary data was collected to ascertain current thinking in the field of PM in general and the two research questions in particular. A case study was undertaken with a well-established NGO in Pakistan. Semi-structured, face-to-face interviews with the managers of the NGO were conducted using specifically developed pro forma. Primary data were analysed in the light of literature to identify themes and patterns. Finally, findings of this research and suggested conclusion are presented in the later part of this article.

\section{Literature Review}

Scholars and practitioners both agree that in the case of private sector firms it is the profitability and the financial value which determines how a firm is performing. This is not to suggest that only financial measures matter in evaluating performance of a firm. In fact, multi-faceted frameworks like Balance scorecard (Kaplan, 2013) and performance prism (Neely, 2005) are widely used in the private sector and this has been the case for the past several years. These multi-dimensional frameworks also use profitability indicators, the difference is that they include non-financial measures as well. The point is that profit and financial value remains the core of PM in the private sector. Unfortunately, no such single measure exists for NGOs which everyone could agree on and use. Lack of original research on PM in the NGO sector compounds the situation further. Thus, NGOs have been forced to adapt performance metrics developed for private sector organizations (Camp \& Braet, 2016). Unsurprisingly, these adaptations have not been very effective because NGOs are quite different from a traditional private sector firm in terms of structure and objectives.

\section{What is a Non-Governmental Organization?}

In order to appreciate fully why PM designed for private firms may not be effective for NGOs it is important to understand what an NGO is. The term NGO was introduced by the UN in 1945 (Martens, 2013). Historian Peter D. Hall stated although charitable organizations have been in existence for thousands of years it was only since 1970s that society started recognizing these organizations as a distinct sector (Hall, 2010). Americans insist categorizing these organizations as "nonprofits", Europeans prefer to call it "charitable organizations", the World Bank uses the term "development organizations", social scientists have given it their own name i.e. "social organizations" but in Asia the word NGO is widely accepted and commonly used. It is not just the naming issue, defining such organizations is even more challenging because of the diverse nature of these organizations and the fact that boundaries between sectors are becoming rather fluid and are constantly shifting. In fact Martens warned defining NGO is mission impossible hence, it was suggested, one should not waste time in trying to do so. Over time, several definitions of NGO Sector have been proposed by practitioners and scholars. Alcock (2013) justified this multiplicity of definitions by arguing that definitions of NGOs are socially constructed and as social realities vary among people therefore scholars, practitioners and policy makers tend to see concepts from their own unique perspectives, hence debates on definition of key terms is common in literature.

Boris (2006) suggested that NGO sector comprises of private organizations serving public purposes. Cordery and Sinclair (2013) identified voluntary participation and non-distribution of profits as distinguishing features of NGO. Each definition has its own merits and particular focus. For the purpose of this study the definition used is: "NGOs are nonprofit distributing, independent from government organizations which are self-governing (Salamon, 2010), and serve a social cause for community benefit (Boris, 2006)".

From the above definitions it is quite obvious that NGOs are different from the private sector firms in many aspects. The most important distinction is the purpose of organization. The main objective of a typical private sector organization, as Hazlitt (2013) noted is, to create and add financial value for the shareholders whereas NGOs exist for a social purpose (Salamon \& Anheier, 2013). Also, NGOs generally do not have owners or shareholders. Another important difference is in the financial model of 
the two sectors. In the private sector, a company sells its goods and/or services to customers at a price which not only cover its costs but also generate a profit which they can distribute to its owners. Whereas, the NGOs do not generally charge its customers; hence they have to rely on grants and donations and in case of a surplus they cannot distribute it. As there are fundamental differences in objective and financial model of the two sectors not only their structure and activities are different but their cultures are also unique (Waldron, 2017). These are sufficient grounds for NGOs to use performance measuring systems specifically developed for their sector.

\section{What is Performance Measurement?}

Literature provides several definitions of performance measurement, for instance, Payer-Langthaler and Hiebl (2013) saw performance measurement as assessment of the results from intentional action. Whereas, Wadongo and Abdel-Kader (2014) defined it as: "PM is the past, present or future accomplishment of a given organisational task or dimension measured against pre-set known standards of accuracy, completeness, value, or time" (p. 683). Performance measurement has also been defined as a "system" which translates strategies into results (Hall, 2010), or as a "tool" which support the assessment of progress of an organization in moving towards its goal and which may become formalized over time (Cruz, Scapens \& Major, 2011). On the other hand, Franco-Santos, Lucianetti and Bourne (2012), emphasized the multi-perspective aspect of PM in their definition: "PM system in an organization exist if financial and nonfinancial performance measures are used to operationalize strategic objectives" (p. 85).

The common ground of these various PM definitions is the implicit reference to strategy, thus, it can be inferred that in the contemporary literature, role of PM in an organization is expected to be more than simply monitoring the results (Hasan, 2018). Therefore, this article uses the following definition of PM provided by Neely, Gregory and Platts (2005): "PM is a set of metrics used to quantify both the efficiency and effectiveness of actions implemented to achieve the strategic goals of an organisation" (p. 1229).

\section{Performance Measurement in NGOs}

As discussed above NGOs are quite different from private sector firms therefore the tools developed for firms may not fulfil the specific needs of NGOs. Irrespective of whether the NGO needs are satisfied or not, literature provides ample evidence that NGOs use private sector firms PM systems (Phelan, 2014). This mimicking has been explained through the phenomenon of isomorphism i.e. over a period of time organizations tend to become similar by following the more successful organizations or under normative and coercive pressures (DiMaggio \& Powell, 1983; Phelan, 2014). In the last few decades NGOs have become larger and more comparable to private companies in terms of its financial size. It is estimated that in 2016 NGOs transactions totalled \$2.3 trillion globally (World Bank, 2017). This tremendous growth was accompanied by numerous scandals involving NGOs reported around the world gave rise to what is popularly known as accountability movement (Worth, 2014). Competing for scarce resources NGOs were forced to be more transparent and accountable for what they were doing with the resources provided to them. Lloyd, Oatham and Hammer (2007) defined accountability as the mechanism through which NGOs commit to consider the expectations of stakeholders in its decisionmaking and delivering against this commitment. Whilst it makes sense that NGOs must be held accountable but it is not clear that it should be accountable to whom and for what (Ebrahim, 2010). Traditionally, donors and regulators demand financial and activity reports from NGOs and thus it became standardized to prepare and submit these reports. However, Ospina, Diaz, and O'Sullivan (2013) objected to this limited concept of accountability which simply prescribe disclosure of financial indicators and compliance with regulations as, they pointed out, these actions do not provide stakeholders with information about how well an organization is achieving its mission and goals.

O'Dwyer and Boomsma (2015) used the concept of Fry's "felt accountability" - a voluntary response to mission based on ethical values of employees - for arguing that with felt accountability the NGOs focus more on how accountability can be used to develop a shared internal vision and are not concerned if it is being pushed by the donor. In support of this argument, Agyemang, O'Dwyer, 
Unerman, and Awumbila (2017) found that employees, especially the fieldworkers, were inclined to consider themselves more accountable to the beneficiaries irrespective of the donor-imposed accountability processes. Ebrahim and Rangan (2014) summed it up well, they concluded accountability is not just compliance it includes requirement to produce results.

There is a growing group of scholars who warn against the domination of external accountability driven processes. Literature suggests that a PM system driven only by accountability without considering the informational needs of the organization can be misleading and even can affect performance negatively (Ebrahim, 2010). Scholars strongly advocate that PM should be guided by the concern for capacity building and improvement (LeRoux \& Wright, 2010). Operational efficiency and continuous improvement, Moxham (2009) suggested, can only be achieved in an NGO through a robust performance measuring process in the organization. Capacity building is advantageous for the organization in many aspects. Connolly and Lukas (2002) found capacity building boosts organizational impact and increases sustainability. Goh and Ryan (2008) reported that organizations with higher learning capacity consistently outperformed competitors because they were "better at knowledge transfer and generating new knowledge to solve problems" (p. 225). On a similar note Kaplan (2013) contended that PM issue in NGOs has become serious because of increasing competition for scarce donor resources and this has pushed NGOs to over-focus on financial indicators which are not good in showing long-term value creation. He suggested, NGOs should measure how efficiently and effectively they are meeting the needs of their constituencies.

\section{NGOs in Pakistan}

Pakistan is the fifth largest country of the world by population. It is inhabited by 207 million people with a per capita income of $\$ 1550$ (CIA World fact book, 2018). With such a small per capita GDP, big variance in distribution of income and a literacy level of under $60 \%$, it is not surprising to note that $25 \%$ of the population lives below the line of poverty (Pakistan Economic Survey, 2018). With no significant exportable natural resources, low level of industrialization and non-mechanized farming combined with a large unskilled population, tax base is only $0.6 \%$ (Finance Bill, 2018) hence government revenue is very limited. The country has to periodically borrow from international lending agencies such as IMF and EXIM bank of China. These large loans have cyclic effect and cost the nation $37 \%$ of the total budget. Another $19 \%$ of the budget is spent by the country in maintaining a large army necessitated due to hostile relations with its neighbours. This leaves only $44 \%$ of the national budget available to the planners to run government and for doing development projects. In such situation very little funds can be allocated for social welfare. For instance only $\$ 127$ million were provisioned for health services in 2018 budget translating to $\$ 2.5 /$ year per person. In a country with 50 million people living below the poverty line this is grossly inadequate and so NGOs have stepped in to fill the gap. More than 1,000 NGOs are actively working in Pakistan in the health sector at the moment (Pakistan Centre for Philanthropy, 2017).

An NGO can be established in Pakistan under any of these four laws: Societies Registration Act of 1860; the Trust Act of 1882; the Voluntary Social Welfare Agencies (registration and control) Ordinance of 1961; and the Companies Act 2017. Therefore, no single agency in the country has complete data on NGOs in Pakistan. In any case rules that apply to the NGOs under these laws are quite basic and simple. Foreign NGOs are subjected to extensive scrutiny for fear of terrorism funding but local NGOs have only minimal compliance requirements. This is in stark contrast to the private sector firms which many feel are over-regulated by Security and Exchange Commission of Pakistan. As mentioned earlier there are about 45,000 NGOs currently operating in Pakistan. For NGOs in Pakistan, there are no restrictions on generating resource. However, the Primary source of funding for most NGOs in Pakistan where 97\% of the people are Muslims is Zakat which is obligatory religious charity (Afaq, 2013). This means a large number of people donating small amounts and not just a few large donors. The implication is that it is the donors who approach the NGO to donate and the NGO can target donors only through broad-based advertisements and not by personal selling. 


\section{Methodology}

For this research qualitative methodology was used. The main reason for preferring qualitative methodology for this study was the complexity of the phenomenon investigated i.e. performance measurement. PM is embedded in social and behavioural aspects of humans suggesting presence of complex underlying phenomena which are at play in the organizations. Scholars such as Patton (2015) recommended qualitative approach to investigate complex phenomenon.

Instrumental case study method was adopted for this research. Instrumental case study means researcher examines a particular case only to provide insight into an issue. Primary interest of the researcher is in the issue and the case organization only facilitates in understanding the issue (Stake, 2000). This method was selected for several reasons; firstly, case study approach produces rich data which lends itself to deeper levels of understanding; secondly, this study was exploratory in nature for which case study method provides enough flexibility, thirdly, participants were accessible whose behaviour couldn't be manipulated by the researcher, and finally, all types of evidence including documents, interviews, and observations can be used in case study method. In such situation, Yin (2014) suggested researchers should use case study method. Obviously it is difficult to generalise from single case study, we agree with the assertion made by Nudurupati, Tebboune and Hardman (2016) that "a single case study can be central to scientific development and act as the force of example..... the use of a single case study is more natural in describing the case and hence capable of delivering richer theoretical insight" (p. 229).

Critical realism was preferred as ontological orientation of this research. The proponents of critical realism believe that the main purpose of research is to critique and challenge prevailing assumptions and beliefs and not just simply describing them. The word "critical" here emphasises rejection of claims of universal truth (Denzin \& Lincoln, 2013). Critical realism, Parker (2014) observed, offers an opportunity for researchers to explore "marginalized subject-matter" and perhaps due to this the approach is becoming more popular among academic researchers from various disciplines. Since PM issues in NGOs have not been explored in detail, it may be considered as marginalized subject matter.

The main principle in selecting organization/s or individuals in a qualitative study, Maxwell (2013) stated, is to identify organizations and individuals that best exhibit the phenomenon which is being studied. Keeping that as a guiding principle a mid-sized, mature NGO working in health sector based in Karachi, Pakistan was finally selected. However, as requested by the NGO, its identity is kept confidential and is referred to as NGO in this study. Semi-structured interviews were conducted using the instrument adapted from Bogdan and Biklen (2007). Documents were gathered from both external and internal sources. External sources include organization's official website, newspapers, and other public domain sources. A copy of organization's functional organigram, manuals, publications, relevant forms and templates, reports submitted to donors, audit reports, annual reports, proposals sent to donors, and newsletters were collected directly from the organization. These documents contributed in developing understanding about the processes and practices of performance measurement in the organization.

\section{Findings}

Recall the two research questions formulated for this study were:

RQ1: Why an NGO measure its performance? and

RQ2: What drives design of performance measuring system in an NGO?

Twenty-six employees, serving as managers or senior officers, of the selected NGO participated in the semi-structured, in depth interviews. In addition, three patients and two representatives of associated pharmaceutical firms were also interviewed. The purpose of interviewing non-employees was to corroborate some of the information provided by the employees. 
Analysis and interpretation of data collected from interviews, detailed scrutiny of relevant documents, personal observations during site visits and reflections of the researchers generated two primary findings as presented in the following sections.

\section{Finding 1: Performance is measured for sustainability}

In response to the first research question why an NGO measures its performance, it was found that the managers of the NGO believed that they must measure and report performance regularly to survive in an environment of fierce competition for resources. Thus the main objective of PMS in this NGO was to help the organization remain sustainable.

\section{Finding 2: Legitimacy drives PMS design}

Corresponding to the second research question about what factor drives the design of PMS in an NGO, it was found that the design of PMS in the NGO was highly influenced by its managers' desire to maintain legitimacy. In this NGO decisions about all activities and systems, including PMS, were taken considering how it will affect credibility of the organization in the eyes of its different stakeholders. Review of PM evolution over the last decade in the NGO and detailed analysis of its current indicators and measures showed that managers had ensured that their concerns about organizational credibility were addressed by PMS. All major and even minor changes in the structure and design of PMS were found to be focusing on identifying the elements which were considered as a risk to credibility.

\section{Discussion}

While compliance requirements in Pakistan are minimal for NGOs, donors expect a detailed account of activities of the NGO before they decide to give. Better produced reports and show-casing good performance of NGO are looked at favourably by the donors. Noting that more than half of the new registered NGOs in Pakistan do not survive for longer than two years (Nisaa et. al., 2015), it can be inferred that the failing NGOs could not convince donors about its performance. Thus, performance reporting is a key challenge NGOs are facing in Pakistan. Talking about performance measurement system one participant of the NGO said:

"Our PMS is not a stand-alone process; it is a more like a network serving multiple functions. [It] provides data for strategic planning, helps us in identifying our weak areas and most importantly, it provides evidence that we are achieving our mission. All of these outputs [of PMS] help us survive in the cut-throat competition (participant 4, August 15, 2018)".

Another participant offered a different insight; she said their PMS delivered all what it was supposed to, additionally, it also removed communication barriers within different stakeholders of the organization which proved to be immensely helpful in projecting a positive image of the NGO (Participant 17, August 16, 2018). In the context of PM reference to reputation or credibility was made by a number of participants indicating that participating managers believed not only the two were linked but also that this link was important. This thought is supported by literature where evidence provided by research is growing that NGOs are very concerned about their credibility. Conway, O'Keefe and Hrasky (2015) reported that substantial government funding is available to a typical NGO in Australia but still on an average they need to self-generate 49 percent of its income through fund raising activities and to do that an NGO has to compete with thousands of other NGOs. This competition for limited resources combined with the requirement of meeting society's expectations makes credibility very relevant for NGOs. Situation in Pakistan is much worse as hardly any funding is available from the government nor large organizational donors' exits. Thus NGOs are heavily dependent on general public to raise funds. In such cases, reputation and public image gains paramount importance (Bennett \& Ali-Choudhury, 2009). NGOs failing to raise adequate funds vanish very rapidly as banks and other financial institutions are reluctant to provide any loan to them (Afaq, 2013). A typical NGO in Pakistan needs two types of funds; one is core funding which is required to maintain 
their core structure and functions; and the other is project funding which is needed for field activities. While both are needed for long-term sustainability, no NGO can survive without core funding even in the short-term. However, the dilemma is that donors are more inclined to fund projects or field activities as in this case they can usually see verifiable, tangible results. Therefore, the competition for core funding is incredibly tough and NGOs in Pakistan seem to be struggling to raise funds for their core structure. It is easy to see that those NGOs which enjoy higher credibility are more likely to get core funding. Furthermore, it makes sense for these NGOs to carefully monitor its credibility on a regular basis and be ready to take corrective action if needed. This could perhaps also explain the low survival rate of NGOs in Pakistan.

It was noted that this NGO monitored five areas of growth, efficiency, sustainability, quality, and social impact to measure its performance. While several regular quantitative indicators e.g. ratios and numbers formed a part of PMS much more weightage was assigned to the qualitative indicators. Each of the five areas was measured by at least one qualitative indicator. Also, their PMS included indicators not just from the internal processes but also from media, donors, beneficiaries, employees, and civil society i.e. all of the major stakeholders of the NGO. For example, sustainability was measured through perception of media about reputation of the organization, and similarly, quality was measured by asking the beneficiaries how they valued the services they had received. In this NGO, it was noted, performance measurement has evolved quite drastically over the past several years. When it started operations in the 1980s it didn't have any formal or even informal mechanism of PM. The evolution of PM in this NGO maybe divided into three distinct periods. In the beginning, quite understandably, the focus was on building the infrastructure and basic delivery processes. During this period that lasted till 1990 no measurement or monitoring of outputs or processes were consciously done. Progress updates were reported verbally in meetings and only sketchy records were kept. As the organization expanded rapidly a need was felt to establish a mechanism for standardized reports. Hence, all departments were asked to start maintaining proper records and a few simple reports were designed which the departments were required to submit on a monthly basis. This phase lasted for almost two decades. During this period organizational operating procedures were standardized, more output and progress reports were added and these were regularly assessed and refined. This phase also saw the conversion of manual systems to computerised recording and processing. In 2008, the NGO established quality assurance department which marked the start of the third phase of PM in the organization. This department not only helped in streamlining the procedures but also tried to integrate different systems. Currently, all functional areas and departments of the NGO are fully covered by PMS.

Availability of integrated information led to a paradigm shift in the organization. Administrative departments including finance, human resources, marketing, fund-raising, communication, MIS, purchasing, all started seeing how their tasks were inter-connected and could have important implications on outside stakeholders. This attitude helped build organization's goodwill as in Pakistani society honest and unsolicited praise is highly valued. In the words of one participant:

\section{"My department's work does not involve a lot of interaction with outsiders. So I was quite surprised when I heard in a TV interview of a very famous person that he considered our NGO as highly credible because he noticed staff in my department behaving very professionally even when they thought they were unobserved. The interview was not about our organization nor the person was affiliated with us in any way (participant 13, August 17, 2018)".}

Another significant change that was brought about by integration and comprehensive reporting was that the statistics in the reports were personified by the managers. Beneficiaries were no longer seen as numbers rather they were perceived as fellow human beings. One manager remembered a hearttouching human life incident and said that the story was picked up by the print media which created quite a stir. He said, "immediately after the story was printed we saw pouring in of commending messages, received inquiries of how can they help. [As a result] we saw immediate increase in pledges and donations" (participant 4, August 15, 2018). 
The incident happened in 2009 and perhaps at that specific point the NGO realised the tremendous power of human life stories. In fact this change was also evident from the promotional material reviewed. Prior to 2009, the main message of the NGO pamphlets, advertisements and annual reports was about how many beneficiaries were served or how many new units were opened. However, from 2009 onwards a clear change in the "sales pitch" was observed. For the first time, a beneficiary's story was included in the annual report of 2009. All of the NGO's current promotional material now highlights the real life stories of the beneficiaries and how dramatically their families' lives were changed with the intervention of this NGO. Power of these heart-warming success stories cannot be denied because these are so appealing and people can connect easily to these. As an implication those who have donated are happy to see their money causing spectacular positive changes in lives of other people so they are inclined to donate to the NGO even more. Such stories had never been uncommon at this NGO but earlier these were not properly captured or documented. A mechanism has now been established and staff is professionally trained so that these stories are not lost and can be effectively used.

Once it was clear that managers of NGO value organizational credibility highly it was not difficult to see that the design of PMS and changes made in it were based on the objectives of establishing, sustaining and improving credibility of the organization. As PMS of this NGO tracked growth, efficiency, sustainability, quality and social impact for measuring performance so to a casual observer it might seem that NGO is concerned about growth, efficiency and other aspects. However, this research revealed that the NGO was not targeting growth nor was it overly concerned about process efficiencies and even financial sustainability was not a big issue for them. Their main goal was to maintain legitimacy.

Legitimacy is a complex phenomenon, defined as a "generalized perception or assumption that the actions of an entity are desirable, proper or appropriate within some socially constructed system of norms, values, beliefs and definitions" (Suchman, 1995, p. 574). While Suddaby, Bitektine and Haack (2017) saw legitimacy as collective consensus judgment or validation by outsiders which is built over time. Legitimacy can also be seen as process of persuading and influencing others (Muchnik, Aral, \& Taylor, 2013). As this NGO has been in existence for about thirty years, it considered itself as "legitimate" after having crossed the threshold which Suddaby "called tipping point in the process of legitimacy" (p. 464) many years ago. The NGO intensely guards its legitimacy as its most valued "intangible asset" by continuously engaging in considerable legitimacy work through adoption of legitimate structures, practices and symbolism. This pragmatic approach to legitimacy, Suchman (1995) said, keep on reminding outsiders that the organization is credible. Analysis of seemingly disparate array of indicators which this NGO used in its PMS shows they all have roots in legitimacy. Review of PM evolution over the last decade and detailed analysis of its current indicators and measures demonstrated that managers had ensured through making appropriate changes in PMS that their concerns about organizational credibility were all addressed. All major and even minor changes in the structure and design of PMS were found to be focused on identifying and minimizing the elements which were considered a risk to their credibility. The emphasis of PMS on measuring performance through perception of stakeholders for instance related to efficiency provides a strong evidence that the NGO tracked efficiency not because it wanted to become the most efficient organization rather it was done to maintain a good image among its stakeholders.

This NGO is a success story as it has not only managed to survive but also have consistently grown for the last thirty years. It demonstrates that their unique operating style has been successful in the Pakistani environment. The operating style mentioned here refers to the impression management strategy which this NGO follows. Impression management is the behaviour or actions of an organization consciously done to get favourable reactions from others (Conway et. al., 2015). As mentioned earlier, all major decisions in this organization were made with the consideration that how will it appear to their stakeholders. Whilst it must be commended that an NGO is so concerned about its external stakeholders, it has a down side as well which is that the NGO tends to glorify its even trivial achievements. It was noticed that annual reports of this NGO included several human life stories but little information was shared on financial affairs. No evidence was seen that informed consent was 
obtained from guardians of children whose real life stories were show-cased in reports depicting their real names and pictures. Clearly, in this instance, show-casing of outputs, ostensibly to maintain legitimacy, has taken precedence over accountability. Will it have any negative impact on the NGO, only time can tell.

\section{Conclusion, Limitations and Recommendations}

To conclude, it is suggested that the purpose of performance measurement in this NGO was to ensure that its sustainability is maintained. Design of NGO's PMS was highly influenced by the desire of its managers that the organization must appear legitimate in the eyes of its stakeholders. Since, all organizations are situated in their respective social contexts which interact with the processes of the organization, it will be unwise to assess organizational performance without referring to its specific context. The affects of this social interaction are even more pronounced in the case of NGOs as the objective of a typical NGO is serving a social need and not to increase shareholders wealth or to gain more votes.

Donors, beneficiaries, media and employees are the main actors in the echo system of any NGO and the credibility the NGO enjoys in the eyes of these actors determine whether the NGO is sustainable or not. Hence, it is suggested that this credibility of an NGO among its stakeholders i.e. its legitimacy is the main determinant of the success of the NGO. This case demonstrated that NGOs which astutely monitor factors affecting its credibility through PMS or other systems, and diligently act to attain and maintain high level of legitimacy stands a better chance of sustaining, and even growing, as compared to those NGOs which ignore such factors.

As with all research, the results of this study need to be considered in the light of its limitations. The analysis was confined to one NGO in the health sector and data was collected and analyzed only from the perspective of Managers.

Future research may be conducted by including other stakeholders and selecting NGOs from other sectors which could help in deepening the understanding of the issue of performance measurement and validating the presented results. However, given that little research has been conducted within the NGO sector on drivers of performance measurement system, this research provides useful findings which could be used in further development of the concept. The paper specifically contributes by extending prior performance measurement literature in an NGO environment. It raises issues about how primary focus of reporting in NGOs in Pakistan is shifting from accountability to show-casing which needs further research as none exist currently.

\section{References}

Afaq, A. (2013). Capacity development and leadership challenges in the NGO sector of Pakistan. $\mathrm{PhD}$. Florida State University College of Social Sciences and Public Policy.

Agyemang, G., O’Dwyer, B., Unerman, J., \& Awumbila, M. (2017). Seeking conversations for accountability: Mediating the impact of non-governmental organization (NGO) upward accountability processes. Accounting, Auditing \& Accountability Journal, 30(5), 982-1007.

Alcock, P. (2013). A Strategic Unity: defining the Third Sector in UK. In Osborne, S. (Ed.), Voluntary and non-profit management (pp. 37-60). London: Sage Publications.

Bennett, R. and Ali-Choudhury, R. (2009). Second-gift behaviour of first-time donors to charity: an empirical study. International Journal of Nonprofit and Voluntary Sector Marketing, 14(3), 161-180.

Berk, J., and DeMarzo, P. (2017). Corporate Finance, 4th Edition, Pearson Education.

Bhatti, R.F. (2016). Exploring strategies for effective advocacy: the lived experience of leaders of Pakistani non-governmental organizations. PhD. University of San Diego. 
Bogdan, R., \& Biklen, S. (2007). Qualitative research for education: An introduction to theories and methods. Boston, MA: Allyn \& Bacon.

Boris, E. (2006). Introduction-Nonprofit Organizations in a Democracy: Varied Roles and Responsibilities. In E. T. Boris \& C. E. Steuerle (Eds.), Nonprofits and Government: Collaboration and Conflict (pp. 1-35). Urban Institute Press.

Camp, J., \& Braet, J. (2016). Taxonomizing performance measurement systems' failures. International Journal of Productivity and Performance Management, 65(5), 672-693.

CIA, World Fact Book (2018).

Website. https://www.cia.gov/library/publications/the-worldfactbook/geos/pk.html

Connolly, P. \& Lukas, C. (2002). Strengthening Nonprofit Performance: A Funder's Guide to Capacity Building. Saint Paul, MN: Wilder Publishing.

Conway, S., O'Keefe, P., \& Hrasky, S. (2015). Legitimacy, accountability and impression management in NGOs: the Indian Ocean tsunami. Accounting, Auditing \& Accountability Journal. 28 (7), 1075-1098.

Cordery, C. \& Sinclair, R. (2013). Measuring performance in the third sector. Qualitative Research in Accounting \& Management. 10(3/4), 196-212.

Cruz, I., Scapens, R. W., \& Major, M. (2011). The localisation of a global management control system. Accounting, Organizations and Society, 36(7), 412-427.

Denzin, N.K. \& Lincoln, Y. S. (2013). Strategies of qualitative inquiry. SAGE Publications.

Di Maggio, J. \& Powell, W. (1983). The iron cage revisited: institutional isomorphism and collective rationality in organizational fields. American Sociological Review,48(2), 147-160.

Ebrahim, A. (2010). The many faces of nonprofit accountability. In Renz. D. (ed.), The Jossey-Bass Handbook of Nonprofit and Management (pp. 101-121). San Francisco: Jossey-Bass.

Ebrahim, A. \& Rangan, V. K. (2014). What impact? A framework for measuring the scale and scope of social performance. California Management Review, 56(3), 118-141.

Finance Bill (2018). Federal Board of Revenue, Government of Pakistan. https://www.fbr.gov.pk/budget2018-19/FinanceBill.html

Franco-Santos, M., Lucianetti, L. \& Bourne, M. (2012). Contemporary performance measurement systems: a review of their consequences and a framework for research. Management Accounting Research, 23(2) 79-119.

Goh, S.C. \& Ryan, P.J. (2008). The organizational performance of learning companies: a longitudinal and competitor analysis using market and accounting financial data. The Learning Organization, 15(3), 225-239.

Hall, P. D. (2010). Historical perspectives on nonprofit organizations in the United States. In R. Herman, R. \& Renz, D. (Eds.), The Jossey-Bass Handbook of Nonprofit Leadership and Management (pp. 3-41). San Francisco, CA: Jossey-Bass.

Hazlitt, H. (2013). The Function of Profits.Economics in One Lesson. Ludwig Von Mises Institute.

Kaplan, R. (2013). Strategic Performance Measurement and Management in Nonprofit Organizations. In Osborne, S. (Ed.), Voluntary and non-profit management (pp. 149-167). London: Sage Publications.

LeRoux, K. \& Wright, N. (2010). Does performance measurement improve strategic decision making? findings from a national survey of nonprofit social service agencies. Nonprofit and Voluntary Sector Quarterly, 39(4), 571-587.

Lloyd, R., Oatham, J., \& Hammer, M. (2007). 2007 global accountability report. London: One World Trust.

Maas, K. \& Liket, K. (2011). Social impact measurement: classification of methods. In Burritt, R. Schaltegger, S., Bennett, M., Pohjola, T. \& Csutora, M. (Eds.), Environmental Management Accounting and Supply Chain Management (pp. 171-202). Springer, New York, NY.

Maxwell, J. A. (2013). Qualitative research design: An interactive approach (3rd ed.). Thousand Oaks, CA: Sage.

Martens, K. (2013). Mission Impossible? Defining Nongovernmental Organizations. In Osborne, S. (Ed.), Voluntary and non-profit management (pp. 167-182). London: Sage Publications.

Moxham, C. (2009). Performance measurement: examining the applicability of the existing body of knowledge to nonprofit organisations. International Journal of Operations and Production Management, 29(7),740-763. 
Moxham, C. (2014). Understanding third sector performance measurement system design: a literature review. International Journal of Productivity and Performance Management, 63(6),704-726.

Muchnik, L., Aral, S., \& Taylor, S. J. (2013). Social Influence Bias: A Randomized Experiment. Science, 341: 647-651.

Nazuk, A. \& Shabbir, J. (2018). A new disclosure index for Non-Governmental Organizations. PLoS ONE 13(2): e0191337. https://doi.org/10.1371/journal.pone.0191337

Neely, A. (2005). The evolution of performance measurement research: developments in the last decade and a research agenda for the next. International Journal of Operations \& Production Management, 25(12),1264-1277.

Neely, A., Gregory, M.,\& Platts, K. (2005). Performance measurement system design: A literature review and research agenda. International Journal of Operations \& Production Management, 25(), 1228-1263.

Nisaa, Z., Javed, U., Akhtar, H. (2015). Impact of Project Performance Measurement System on Project Success: A Study Based on NGO Sector of Pakistan. International Journal of Sciences: Basic and Applied Research, 22(2), 289-315

Nudurupati, S. S., Tebboune, S., \& Hardman, J. (2016). Contemporary performance measurement and management (PMM). Digital economies Production Planning \& control, 27(3), 226-235. http://dx.doi.org/10.1080/09537287.2015.10926

O'Dwyer, B. \& Unerman, J. (2008). The paradox of greater NGO accountability: a case study of Amnesty Ireland. Accounting, Organizations and Society, 33(7), 801-824.

Osborne, S. P. (2013). Editor's introduction: The voluntary core of the non-profit sector. In Osborne, S. (Ed.), Voluntary and non-profit management. London: Sage Publications.

Ospina, S., Diaz, W., \& O'Sullivan, J.F. (2013). Negotiating accountability: Managerial lessons from identify-based nonprofit organizations. In Osborne, S. (Ed.), Voluntary and non-profit management. London: Sage Publications.

Pakistan Centre for Philanthropy. (2017). The state of individual philanthropy in Pakistan. http://www.pcp.org.pk/uploads/nationalstudy.pdf

Pakistan Economic Survey. (2018). Economic Adviser's Wing, Finance Division, Government of Pakistan. www.finance.gov.pk

Parker, L. (2014). Qualitative perspectives: Through a methodological lens. Qualitative Research inAccounting and Management, 11(1), 13-28.

Doi: http://dx.doi.org/10.1108/QRAM-02-2014-0013.

Patton, M. Q. (2015). Qualitative evaluation and research methods (4th ed.). Thousand Oaks, CA: Sage.

Payer-Langthaler, S. \& Hiebl, W. (2013). Towards a definition of performance for religious organizations and beyond: a case of Benedictine abbeys. Qualitative Research in Accounting \& Management, 10(3/4), 213-233.

Phelan, F. (2014). Case Study of a Private Nonprofit Foundation's Adaptation of the Performance Management Process and the Relationship to Isomorphic Pressures from a Microfoundation Perspective. PhD. George Washington University.

Rasheed, M. A., Shahzad, K., Conroy, C., Nadeem, S., \& Siddique, M. U. (2017). Exploring the role of employee voice between high-performance work system and organizational innovation in small and medium enterprises. Journal of Small Business and Enterprise Development, 24(4), 670-688. https://doi.org/10.1108/JSBED-11-2016-0185

Salamon, L. M. (2010). Putting the civil society sector on the economic map of the world. Annals of Public and Cooperative Economics, 81(2), 167-210.

Salamon, L., \& Anheier, H. K. (2013). Social origins of civil society: explaining the nonprofit sector cross-nationally. In Osborne, S. (Ed.). Voluntary and non-profit management (pp. 3-36). London: Sage Publications.

Saxena, S. \& Muhammad, I. (2018). Barriers to use open government data in private sector and NGOs in Pakistan. Information Discovery and Delivery, 46(1), 67-75.

https://doi.org/10.1108/IDD-05- 2017-0049 
DOI: https://doi.org/10.47405/mjssh.v6i9.1025

Stake, R. E. (2000). Case Studies. In N.K. Denzin \& Y.S. Lincoln (2nd ed.), Handbook of qualitative research (pp. 435-454). Thousand Oaks, CA: Sage.

Suchman, M.C. (1995). Managing legitimacy: Strategic and institutional approaches. The Academy of Management Review, 20(3), 571-610.

Suddaby, Alex Bitektine, \& Patrick Haack. (2017). Legitimacy. Academy of Management Annals, 11(1), 451-484.

Wadongo, B., \& Abdel-Kader, M. (2014). Contingency theory, performance management and organisational effectiveness in the third sector: A theoretical framework. International Journal of Productivity and Performance Management, 63(6), 680-703.

Waldron, J. M. (2017). A Case Study of Emerging Leaders in the Nonprofit Sector. PhD. St. Thomas University, Florida

World Bank (2017). World Development Indicators database. http://databank.worldbank.org/data/download /GDP.pdf

Worth, M. (2014). Nonprofit management: Principles and practice. Thousand Oaks, CA: Sage.

Yin, R. K. (2014). Case Study Research: Design and Methods. 5th ed. Thousand Oaks, CA: Sage 